SAINS TANAH - Journal of Soil Science and Agroclimatology

Journal homepage: http://jurnal.uns.ac.id/tanah

\title{
Dryland land-use conflicts in humid tropics: an analysis using geographic information systems and land capability evaluations
}

\author{
Risma Neswati ${ }^{1 *}$, Sumbangan Baja ${ }^{1}$, Samsu Arif ${ }^{2}$, Hasni ${ }^{1}$ \\ ${ }^{1}$ Department of Soil Science, Hasanuddin University, Makasar, Indonesia \\ ${ }^{2}$ Department of Physics, Hasanuddin University, Makasar, Indonesia
}

\begin{tabular}{|c|c|}
\hline ARTICLE INFO & ABSTRACT \\
\hline Keywords: & This study analyses land-use conflicts in specific dryland agricultural areas in relatively dry \\
\hline Drylands & humid tropics based on the Regional Spatial Land Use Planning Regulations and land- \\
\hline Land capability & capability evaluation. This research was conducted in the Regency of Jeneponto, South \\
\hline Land conflict & Sulawesi, Indonesia. The observation site was chosen based on several maps overlapping \\
\hline Land use & $\begin{array}{l}\text { to produce } 30 \text { land units spread across } 14 \text { land systems in Jeneponto. This study integrates } \\
\text { ground surveys and geographic information systems technology. The land capability }\end{array}$ \\
\hline Article history & analysis used a simple approach factor, according to United States Department of \\
\hline Submitted: 2019-12-10 & Agriculture definitions. The results indicate that land capability was dominated by Class IV, \\
\hline Accepted: 2020-06-26 & $\begin{array}{l}\text { which covered } 35,133 \text { ha or } 63.1 \% \text {. Class VI covered } 12,581 \text { ha or } 22.6 \% \text {, Class III covered } \\
\text { up to } 4,378 \text { ha or } 7.9 \% \text {, and Class VIII covered } 3,130 \text { ha or } 5.6 \% \text {. Class VII covered only } 486\end{array}$ \\
\hline * Corresponding Author & hectares, or $0.9 \%$, the smallest area. These results indicate that the dryland area which had \\
\hline Email address: & become a land-use conflict was delineated by Regional Spatial Land Use Planning \\
\hline neswati76@gmail.com & $\begin{array}{l}\text { Regulations. The drylands found in Jeneponto cover } 22,214 \text { ha or } 39.9 \% \text {, which has been } \\
\text { divided into two: an area where non-dryland agriculture was converted into dryland } \\
\text { farming }(16,503 \text { hectares, or } 29.6 \%) \text {, and an area where dryland-farming was converted } \\
\text { into non-agricultural dryland area }(5,711 \text { hectares, or } 10.3 \%) \text {. Interviews with } 50 \text { farmers } \\
\text { in the study location revealed factors that had changed agricultural dryland use into non- } \\
\text { agricultural dryland use; lower incomes due to decreased soil fertility was a crucial factor. }\end{array}$ \\
\hline
\end{tabular}

How to Cite: Neswati, R., Baja, S., Arif, S., and Hasni. (2020). Dryland land-use conflicts in humid tropics: an analysis using geographic information systems and land capability evaluations. Sains Tanah Journal of Soil Science and Agroclimatology, 17(1): 57-62 (doi: 10.20961/stjssa.v17i1.37824)

\section{Introduction}

The decline of national food production is due to the decrease of productive agricultural land as a result of land conversion, including the conversion of paddy fields, and increasing land degradation. A possibility for increasing crop production is the utilization of drylands. The problems these presents are limited rainfall, a long dry season, water scarcity, low soil fertility, and plant unsuitability (Campbell, Lusch, Smucker, \& Wangui, 2003).

The drylands of humid and semi-arid tropics are generally dominated by Alfisols, Ultisols, and Oxisols (Subagyo, Suharta, \& Siswanto, 2000). Oxisols and Ultisols are typically found in humid areas that experience high levels of weathering and leaching and feature low soil fertility; generally, drylands are located on steep slopes and shallow solums. Mountainous areas with gradients over $30 \%$ comprise 51.30 million ha; hilly areas with gradients between 15 and 30\% comprise 36.90 million ha (Hidayat \& Mulyani, 2002). Drylands on steep slopes are prone to erosion, especially if cultivated, and farming cannot be sustained throughout the year due to water scarcity. Jeneponto Regency is in South Sulawesi, Indonesia, which features approximately 37,323 ha of drylands, $49.7 \%$ of the total area (Regulation Regency of Jeneponto No. 1/2012) (Bappeda, 2012).

The land-use conflict surrounding current land use is its nonconformity with regional spatial land-use planning. According to Wirosuprojo (2005), land-use conflicts occur due to conflicts of interest between sectors as a result of population growth. Forms of land use-conflict include 
changes to paddy fields and drylands and forests being converted into residential areas, shops, offices, roads, and transportation facilities.

The potential of land can be based on its ability to support productivity. Land capability is the inherent physical capacity of the land to sustain a range of long-term land uses and management practices without degrading the soil, land, water, or water resources (Dent \& Young, 1981). Land capability is governed by the type of soil, soil depth, texture, geology, topography, and hydrology (Girmay, Sebnie, \& Reda, 2018). Land capability is classified to predict the capability of land development units (Sys, Van Ranst, \& Debaveye, 1991) and limit the land available for various purposes (Panhalkar, 2011). Land capability classifications should accord with the Regional Spatial Land Use Planning Regulations (RSLUPR) by considering the land's suitability.

This study analyzes dryland use conflicts in Jeneponto Regency to understand the impact of the RSLUPR.

\section{Materials and Method}

This research was conducted in Jeneponto Regency, South Sulawesi. This regency is located in an area with an average annual rainfall of $1500-2000 \mathrm{~mm}$, which is relatively dry; according to the Oldeman climate classifications, this is a D3 climate type, meaning it features 4 wet months and 6 dry months. Figure 1 shows the research location. The tools consisted of a computer, the software ArcGIS 10.3 (ESRI Indonesia licensed), a GPS, a soil auger, and a camera. Other materials were a land-system map (scale 1:250,000) (RePPProT, 1986), an RSLUPR map (scale 1:250,000), an existing land-use map (scale 1: 250,000) (KLHK, 2015), questionnaires, and a profile checklist.

This study was qualitative and quantitative and conducted across several stages. The first stage was collecting the primary data from field surveys and questionnaire-style interviews. In contrast, secondary data (digital data and documents from the Jeneponto RSLUPR were obtained from Bappeda (2012). The second stage was field survey maps constructed based on the preparation of work maps obtained using overlapping land-system maps and RSLUPR maps; this resulted in $\mathbf{3 0}$ land units. The third stage was semidetailed field surveys conducted on the 30 land units. For each unit, the soil profile was analyzed, and soil sampling was carried out to analyze soil properties in the laboratory.

Next, dryland productivity data were obtained from 50 respondents from each land unit. The fourth stage was land capability classification, which was obtained by matching land-characteristic data from soil surveys and the results of laboratory analysis according to the United States Department of Agriculture's classification system (Klingebiel \& Montgomery, 1961). This process followed the directions of Arsyad (2010). The fifth stage describing land-use conflict based on the overlapping maps; conflict types were divided into two types: a) unsuitable for non-dryland agriculture, which means the RSLUPR designates the land for dryland agriculture, but there is currently no dryland agriculture; b) unsuitable for dryland agriculture, which means the RSLUPR designates the land for non-dryland agriculture, but there is currently dryland agriculture. The last stage used inputs from 50 farmers in the research area to conduct a factor analysis of conflicts obtained from the correlation analysis. The data used included farmer education, actual land use (status and land area), preferred land use, and the farmer's socioeconomic conditions.

\section{Results}

\subsection{Regional spatial land use planning regulations Jeneponto Regency}

This research was conducted in the Jeneponto Regency, which has a total area of 74,979 ha. Regional land-use planning includes protected areas and areas designated for cultivation (Regency of Jeneponto Local Regulation No. 1/2012). Figure 2 shows the RSLUPR map of the Jeneponto Regency.

\subsection{Existing land use in Jeneponto Regency}

The Jeneponto Regency 2015 land-use map showed 60\% was dryland mixed with dominant shrubs, and $29 \%$ was paddy fields. Table 1 shows existing land use in Jeneponto Regency.

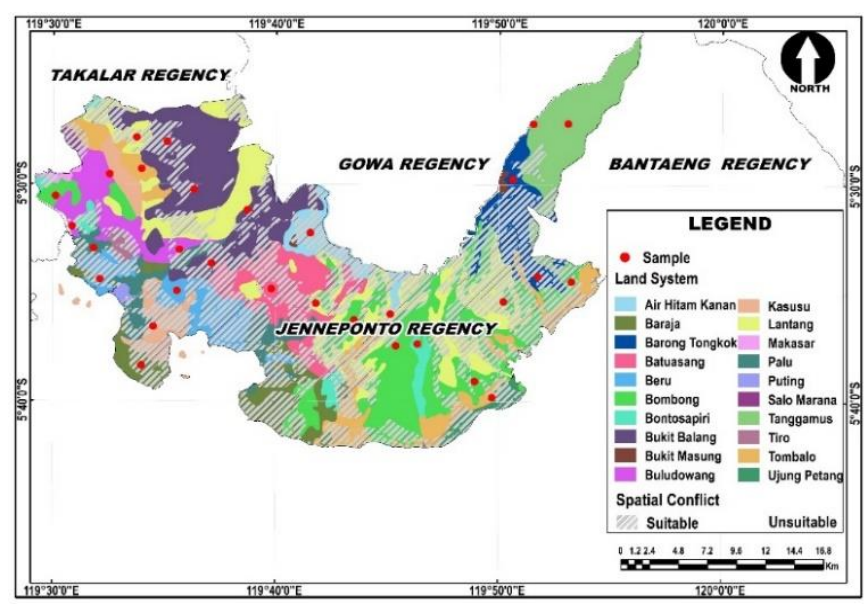

Figure 1. Map of the research area

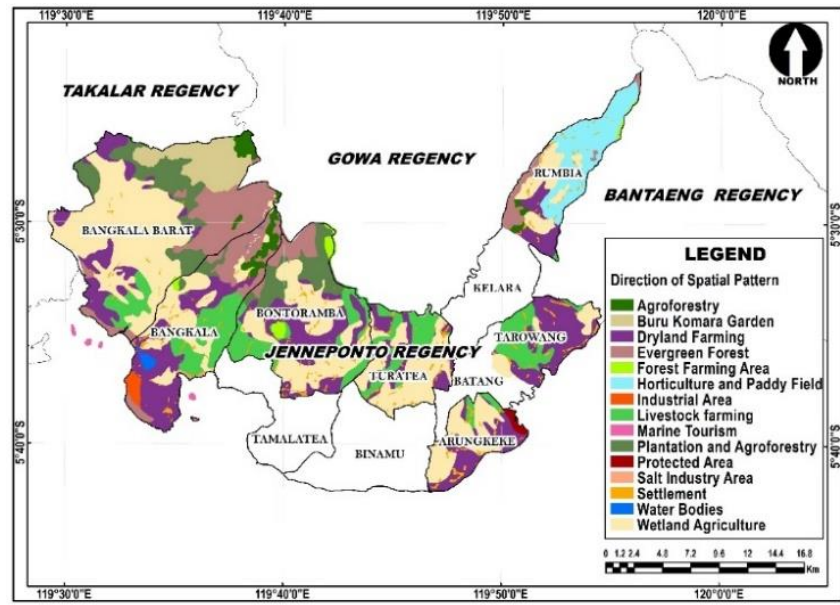

Figure 2. Map of regional spatial land use planning Jeneponto Regency 


\subsection{Land capability classification of Jeneponto Regency}

The land capability analysis showed that approximately $63 \%$ of the land was classified as Class IV, and approximately $23 \%$ of the land was classified as Class VI. The rest of the area was classified as Class III, with an area of $8 \%$, Class VII, with an area of $1 \%$, and Class VIII, with an area of $5 \%$. Arable land (classes I-IV) covered approximately $31 \%$ of the total area. Figure 3 shows the distribution of land capability classifications for the Jeneponto Regency.

\subsection{Distribution of land use conflict in Jeneponto Regency}

Land-use conflicts occur due to conflicts of interests between the community and the government in the determining of the zoning area. Table 2 shows land use stipulated by the 2012 RSLUPR and actual land use in 2015. Figure 4 is the land-use-conflict-distribution map; it compares the dryland area and non-agricultural dryland area in the RSLUPR plan and the existing land in the Jeneponto Regency.

Field observations recognized areas classified as Class VI, VII, and VIII. However, the RSLUPR designated some of these areas for agriculture: land unit 14 (H14), limited by shallow effective soil depth and percentage of rocks on the surface; land unit 19 (H19), limited by gradients of 30-45\% and heavy erosion; land units 20 and 21 ( $\mathrm{H} 20$ and H21), limited by shallow effective soil depth; land unit $28(\mathrm{H} 28)$, limited by high amounts of coarse fragments and a sandy texture. Figure 5 shows the general distribution of conflicts between dryland capability classes.

Table 3 shows that the study also found that land conversion didn't conform with the RSLUPR. Some areas pertaining to land-use Classes VI-VIII, demarcated for dryland agriculture, were converted to non-dryland agriculture: Class VI's 2,041 ha included land units H13, H15, and H25 (Figure 6); Class VII's 2 ha included land unit H22 (Figure 7); Class VIII consisted of 39 ha. However, some non-agricultural dryland was converted to agricultural dryland: 3,436 ha of Class VI, 454 ha of Class VII, and 1,187 ha of Class VIII.

Table 1. Land use existing of Jeneponto Regency

\begin{tabular}{lrr}
\hline Land use & Area (ha) & Area (\%) \\
\hline Dryland secondary forest & 225 & 0.3 \\
Dryland primary forest & 22 & 0.0 \\
Mangrove & 44 & 0.1 \\
Marine tourism area & 115 & 0.2 \\
Settlement & 663 & 0.9 \\
Dryland agriculture & 10,024 & 13.4 \\
Mixed dryland with shrubs & 35,653 & 47.6 \\
Paddy field & 22,071 & 29.4 \\
Shrubs & 3,978 & 5.3 \\
Fishponds & 1,621 & 2.2 \\
Industrial area & 306 & 0.4 \\
Water bodies & 257 & 0.3 \\
\hline
\end{tabular}

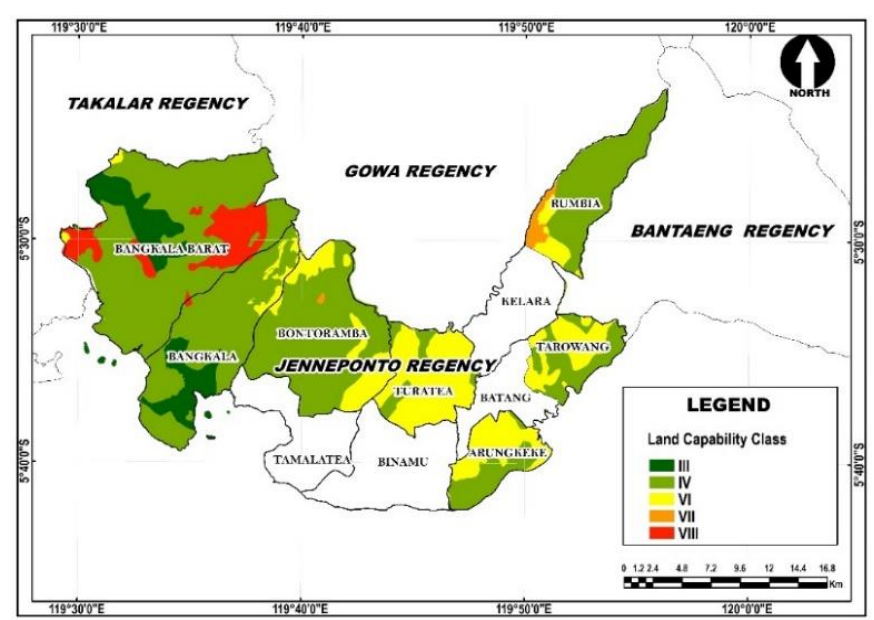

Figure 3. Land capability classification of Jeneponto Regency

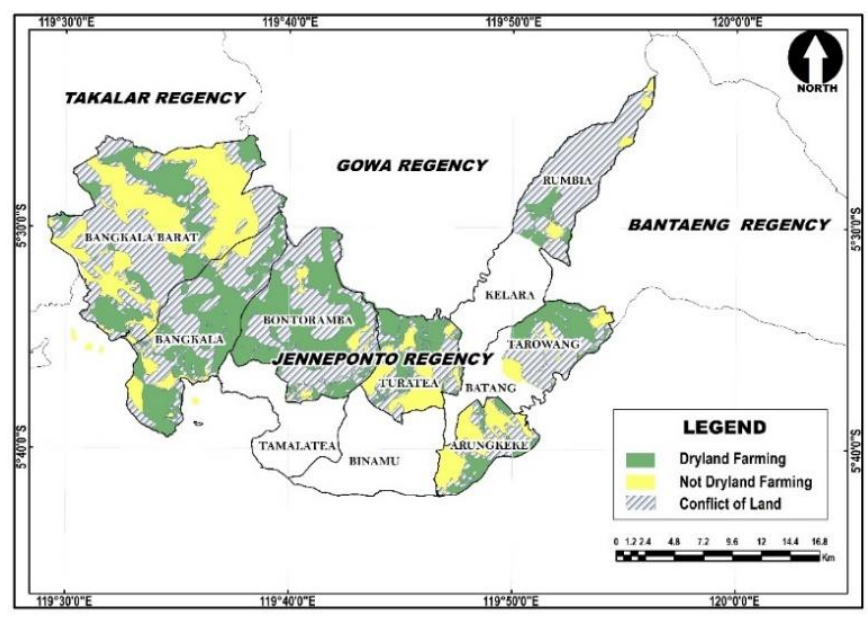

Figure 4. Map of spatial conflict between RSLUPR and existing Land Use in Jeneponto Regency

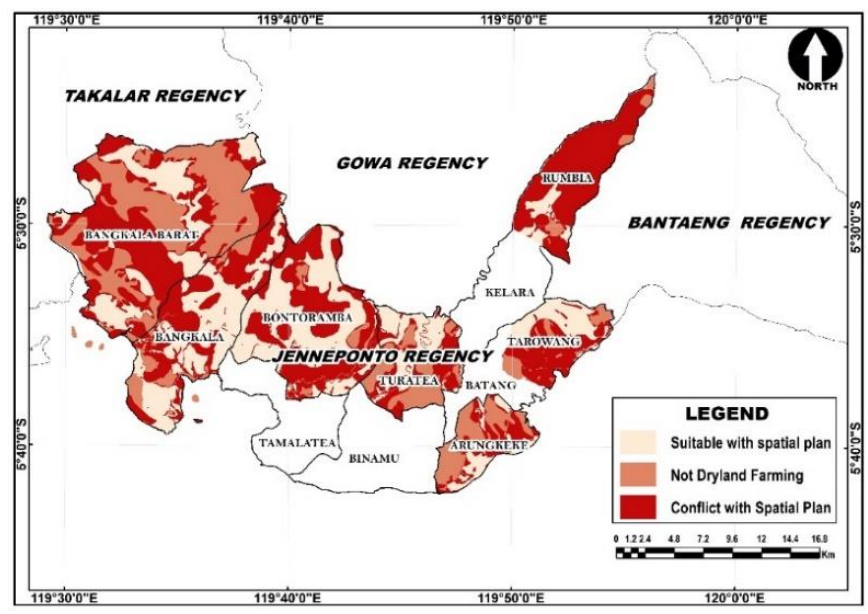

Figure 5. The map of land use conflict, comparison between RSLUPR and existing land use based on land capability analysis in Jeneponto Regency 
Table 2. Matching of land use in RSLUPR and existing land use

\begin{tabular}{cll}
\hline No. & \multicolumn{1}{c}{ Regional spatial planning regulations } & \multicolumn{1}{c}{ Existing land use } \\
\hline 1. & Protected areas, primary forest, production forest & Primary dryland forests, secondary dryland forests, mangrove \\
2. & Industrial area, salt industrial area & Industrial area \\
3. & Marine tourism area & Marine tourism area \\
4. & Dryland agriculture, agroforestry, and plantation, & Dryland agriculture, mixed shrubs dryland \\
& animal husbandry & \\
5. & Wetland agriculture, horticulture and paddy fields & Paddy fields \\
6. & Settlement & Settlement \\
7. & Komara hunting park & Shrubs \\
8. & Fishponds & Ponds \\
9. & Water bodies & Water bodies \\
\hline
\end{tabular}
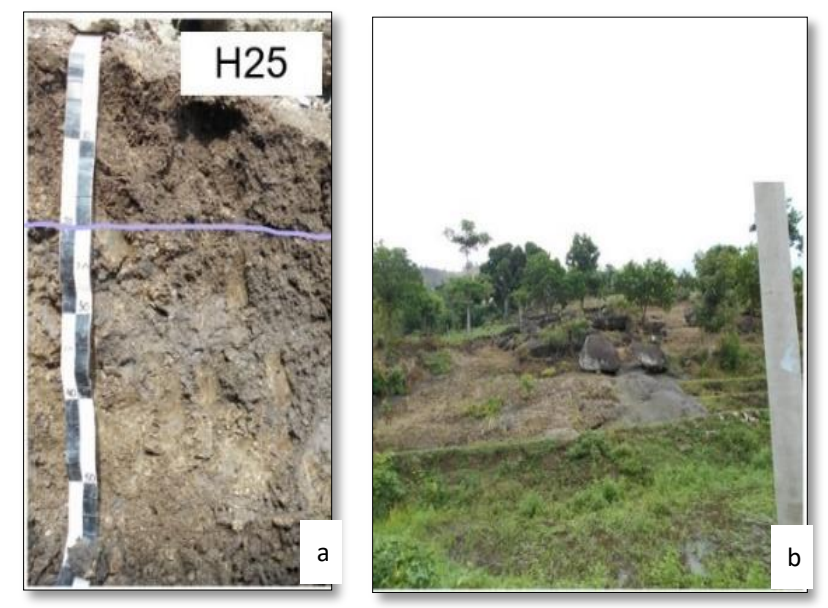

Figure 6. Class VI, unconformity between RSLUPR and existing land use (a) soil profile, (b) existing land use

\section{Discussion}

The study showed that limiting factors were effective soil depth, the percentage of rocks on the surface, percentage gradient, and erosion conditions (see Table 3). Additionally, it showed that land classified as Classes VI-VIII had limited potential due to steep slopes and low soil fertility; thus, the area was unsuitable for agricultural cultivation. Baja (2012) stated that Classes V-VIII must be used for non-agricultural activities. However, they can be used for agricultural land when appropriately managed.

There were land-use conflicts for almost half of the total area of Jeneponto Regency (39.9\%, or 22,214 ha) because of land use that existed before the RSLUPR was stipulated (Figure 5). According to Wirosuprojo (2005), land-use planning must be supported by natural resources, proper analysis, and data processing techniques; as such, suitability and sustainability around natural resources are optimized, and the negative impacts can be kept to a minimum. Table 4 shows that dryland agriculture areas designated by the RSLUPR have been transformed into approximately 5,711 ha of non-agricultural dryland, $10.3 \%$ of the area of Jeneponto Regency. Furthermore, non-agricultural dryland areas designated by the RSLUPR that have been converted into dryland agriculture areas comprised 16,503 ha, 29.6 of Jeneponto Regency.
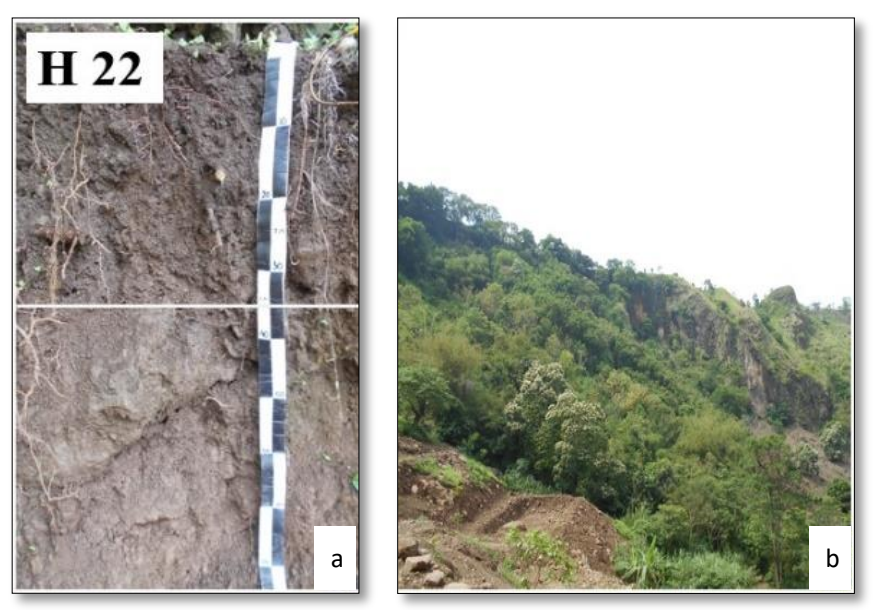

Figure 7. Class VII, unconformity between RSLUPR and existing land use (a) soil profile, (b) existing land use

Dryland cultivation dominates Jeneponto Regency due to inherited land, low farmer income, and dry conditions resulting from water scarcity. Basri, Syakur, and Marta (2013) stated that cultivation has potential as a source of community income. However, the commercial cultivation did not correspond to the RSLUPR due to pressure on areas not designated for agriculture, including protected areas such as forests. Although areas of land capability Classes VI-VIII should be allocated for non-agricultural cultivation, the RSLUPR has directed these classes toward dryland agriculture. Not corresponding to land capability classifications can lead to land degradation.

Table 3 shows that this study observed non-agricultural land use in soils of moderate fertility with flat-to-undulating topography. This indicates that the land use was ineffective, according to the Jeneponto RSLUPR. This discrepancy could be due to land use preceding the RSLUPR's 2012 determination. This accords with Soemarno (2010), who saw conflicts over dryland use as resulting from the conflict between preserving land resources and local economic interests. Additionally, the increasing number of people using land resources has resulted in land extensification that does not follow government policies. 
Table 3. Distribution of land capability classification and distribution of land-use conflicts in Jeneponto Regency

\begin{tabular}{|c|c|c|c|c|c|c|}
\hline Land unit & Land system & $\begin{array}{l}\text { Land capability } \\
\text { classification }\end{array}$ & $\begin{array}{l}\text { Limiting } \\
\text { factor }\end{array}$ & RSPR & Existing & $\begin{array}{l}\text { Conformity/ } \\
\text { Unconformity }\end{array}$ \\
\hline H1 & BDG & IV & $\mathrm{KE}$ & NPLK & NPLK & Conformity \\
\hline $\mathrm{H} 2$ & KAS & III & $\mathrm{T}, \mathrm{KE}, \mathrm{B}$ & NPLK & NPLK & Conformity \\
\hline H3 & TBO & III & $\mathrm{T}, \mathrm{KE}, \mathrm{B}$ & NPLK & NPLK & Conformity \\
\hline H4 & LTG & IV & $\mathrm{KE}, \mathrm{B}$ & PLK & PLK & Conformity \\
\hline H5 & BBG & IV & B & PLK & PLK & Conformity \\
\hline H6 & BRU & IV & $L, E$ & NPLK & PLK & Unconformity \\
\hline H7 & PLU & IV & KE & NPLK & NPLK & Conformity \\
\hline H8 & BRU & IV & $E, B$ & NPLK & PLK & Unconformity \\
\hline H9 & KAS & IV & $\mathrm{KE}$ & PLK & NPLK & Unconformity \\
\hline H10 & BBG & IV & $L, E, B$ & PLK & PLK & Conformity \\
\hline H11 & $\mathrm{AHK}$ & IV & $E, B$ & PLK & PLK & Conformity \\
\hline H12 & LTG & IV & $L, E, K E, B$ & PLK & PLK & Conformity \\
\hline H13 & BOM & VI & $\mathrm{E}, \mathrm{KE}$ & NPLK & PLK & Unconformity \\
\hline H14 & LTG & VI & $K E, B$ & PLK & PLK & Conformity \\
\hline H15 & BOM & VI & $\mathrm{KE}$ & NPLK & PLK & Unconformity \\
\hline H16 & BRI & VI & $\mathrm{KE}$ & NPLK & NPLK & Conformity \\
\hline H17 & BOM & IV & $\mathrm{KE}$ & NPLK & PLK & Unconformity \\
\hline H18 & TBO & IV & $\mathrm{KE}$ & PLK & NPLK & Unconformity \\
\hline H19 & LTG & VI & $L, E$ & PLK & PLK & Conformity \\
\hline $\mathrm{H} 2 \mathrm{O}$ & BTK & VI & KE & PLK & PLK & Conformity \\
\hline $\mathrm{H} 21$ & BOM & VI & $\mathrm{KE}$ & PLK & PLK & Conformity \\
\hline $\mathrm{H} 22$ & BTK & VII & $\mathrm{L}$ & NPLK & PLK & Unconformity \\
\hline $\mathrm{H} 23$ & TGM & IV & $L, E, B$ & NPLK & PLK & Unconformity \\
\hline $\mathrm{H} 24$ & TGM & IV & $L, E$ & NPLK & PLK & Unconformity \\
\hline $\mathrm{H} 25$ & BBG & VI & $L, E, K E$ & NPLK & PLK & Unconformity \\
\hline $\mathrm{H} 26$ & BTS & IV & $L, E, B$ & NPLK & PLK & Unconformity \\
\hline $\mathrm{H} 27$ & BRA & IV & KE & PLK & PLK & Conformity \\
\hline $\mathrm{H} 28$ & BBG & VIII & $\mathrm{T}$ & PLK & PLK & Conformity \\
\hline H29 & BDG & IV & B & NPLK & PLK & Unconformity \\
\hline H30 & BOM & VIII & $\mathrm{T}$ & NPLK & NPLK & Conformity \\
\hline
\end{tabular}

Notes: BGD: Buludowang; KAS: Kasusu; TBO: Tombalo; LTG: Lantang; BRU: Beru; PLU: Palu; AHK: Air Hitam Kanan; BOM: Bombong; BRI: Bontosapiri; BTK: Barong tongkok; TGM: Tanggamus; BTS: Batuasang; BRA: Baraja; KE: Effective soil depth; E: Erosion; L: slope; B: rock; T: soil texture; PLK: dryland agriculture; NPLK: Non- dryland agriculture; RSPR: Regional Spatial Land Use Planning Regulations

Table 4. Distribution of conflict area

\begin{tabular}{clrr}
\hline $\begin{array}{c}\text { Capability } \\
\text { class }\end{array}$ & \multicolumn{1}{c}{$\begin{array}{c}\text { Conformity/ } \\
\text { Unconformity }\end{array}$} & Area (ha) & Area (\%) \\
\hline III & NPLK & 1,763 & 3.2 \\
& Conformity, PLK & 1,125 & 2.0 \\
& Unconformity, NPLK & 543 & 1.0 \\
& Unconformity, PLK & 947 & 1.7 \\
IV & NPLK & 6,967 & 12.5 \\
& Conformity, PLK & 13,023 & 23.4 \\
& Unconformity, NPLK & 3,086 & 5.5 \\
& Unconformity, PLK & 10,479 & 18.8 \\
VI & NPLK & 3,376 & 6.1 \\
& Conformity, PLK & 3,728 & 6.7 \\
& Unconformity, NPLK & 2,041 & 3.7 \\
& Unconformity, PLK & 3,436 & 6.2 \\
VII & Conformity, PLK & 30 & 0.1 \\
& Unconformity, NPLK & 2 & 0.0 \\
& Unconformity, PLK & 454 & 0.8 \\
VIII & NPLK & 1,829 & 3.3 \\
& Conformity, PLK & 75 & 0.1 \\
& Unconformity, NPLK & 39 & 0.1 \\
& Unconformity, PLK & 1,187 & 2.1 \\
\hline
\end{tabular}

Notes: PLK: dryland agriculture; NPLK: Non- dryland agriculture
Table 3 shows that this study observed non-agricultural land use in soils of moderate fertility with flat-to-undulating topography. This indicates that the land use was ineffective, according to the Jeneponto RSLUPR. This discrepancy could be due to land use preceding the RSLUPR's 2012 determination. This accords with Soemarno (2010), who saw conflicts over dryland use as resulting from the conflict between preserving land resources and local economic interests. Additionally, the increasing number of people using land resources has resulted in land extensification that does not follow government policies.

Figure 6 and 7 show that areas that should be used for conservation, due to gradients of more than $45 \%$, have been classified as Class VI-VIII, which means that control measures must be taken. In reality, this area has been widely used for intensive agriculture and has not been accompanied by soil conservation efforts, leading to reduced soil fertility and erosion. Kurnia, Sulaeman, and Muti (2002) stated that agricultural cultivation is carried out continuously throughout the year because it is supported by sufficient rainfall; however, without appropriate soil conservation techniques, land degradation will occur in sloping areas. 
According to Restina (2009), several factors cause changes in land use: low levels of education, land ownership, which is mostly inherited land, low levels of community knowledge about spatial planning, and lack of integration of the RSLUPR with the community. It has also been found that some people want to convert land for agricultural use for economic reasons and to make use of apparently empty land.

\section{Conclusion}

The study indicates that the conflicted area of drylands in the Jeneponto Regency covered 39.9\%, which can be divided into two: non-agricultural drylands converted to dryland agriculture, covering an area of $29.6 \%$, and dryland agriculture converted to non-dryland agriculture, covering an area of $10.3 \%$.

The Jeneponto RSLUPR should be reevaluated because of the discrepancy between the Jeneponto Regency RSLUPR and the evaluation of the land capability of the land units classified as Classes VI-VIII. These results indicate that Classes VI to VIII require conservation measures. However, these land units are often used for intensive agriculture but not accompanied by efforts to conserve the land; this can decrease soil fertility and increase soil erosion.

\section{Acknowledgment}

The authors are deeply thankful to the Ministry for Research, Technology, and Higher Education (Kemenristekdikti), the Republic of Indonesia, for providing research fund through the PSNI Scheme, and the Department of Soil Science, Faculty of Agriculture, Hasanuddin University, for providing data and other support facilities.

\section{Declaration of Competing Interest}

The authors declare no competing financial or personal interests that may appear and influence the work reported in this paper.

\section{References}

Arsyad, S. (2010). Konservasi Tanah dan Air (2nd ed.). Bogor: IPB Press.

Baja, S. (2012). Perencanaan Tata Guna Lahan dalam Pengembangan Wilayah (1st ed.). Yogyakarta: ANDI.

Bappeda. (2012). Perencanaan tata guna lahan dalam pengembangan wilayah kabupaten Jeneponto 20122031. Jeneponto.

Basri, H., Syakur, \& Marta, A. (2013). Penyimpangan Penggunaan Lahan Berdasarkan Rencana Tata Ruang Wilayah Kabupaten Aceh Barat. Roda Teknik Pertanian, 6(1), 383-397.

Campbell, D. J., Lusch, D. P., Smucker, T., \& Wangui, E. E. (2003). Root causes of land use change in the Loitokitok area, Kajiado District, Kenya (No. 19). Nairobi, Kenya.
Dent, D., \& Young, A. (1981). Soil survey and land evaluation. Soil Survey and Land Evaluation., 70(3), 911. https://doi.org/10.2307/2260119

Girmay, G., Sebnie, W., \& Reda, Y. (2018). Land capability classification and suitability assessment for selected crops in Gateno watershed, Ethiopia. Cogent Food \& Agriculture, 4(1), 1532863. https://doi.org/10.1080/23311932.2018.1532863

Hidayat, A., \& Mulyani, A. (2002). Lahan kering untuk pertanian. In Teknologi Pengelolaan Lahan Kering, Menuju Pertanian Produktif dan Ramah Lingkungan. Bogor: Pusat Penelitian Tanah dan Agroklimat Badan Penelitian dan Pengembangan Pertanian.

KLHK. (2015). Penutupan Lahan Tahun 2015 . Retrieved June 30, 2020, from http://geoportal.menlhk.go.id/arcgis/rest/services/KL HK/Penutupan_Lahan_Tahun_2015/MapServer

Klingebiel, A. A., \& Montgomery, P. H. (1961). Land capability classification, Agriculture Handbook No. 210. Washington, D.C.: Soil Conservation Service, U.S. Department of Agriculture.

Kurnia, U., Sulaeman, Y., \& Muti, A. K. (2002). Teknologi rehabilitasi dan reklamasi lahan kering. In $\mathrm{A}$. Adimihardja, Mappaona, \& A. Saleh (Eds.), Teknologi pengelolaan lahan kering, menuju pertanian produktif dan ramah lingkungan. Bogor: Pusat Penelitian dan Pengembangan Tanah dan Agroklimat.

Panhalkar, S. (2011). Land capability classification for integrated watershed development by applying remote sensing and GIS techniques. Journal of Agricultural \& Biological Science, 6(4), 46-55.

RePPProT. (1986). Land system map of Ujung Padang. Bogor: Badan Koordinasi Survei dan Pemetaan Nasional (Bakosurtanal).

Restina, N. (2009). Evaluasi penggunaan lahan eksisting dan arahan penyusunan rencana tata ruang Kota Tasikmalaya Provinsi Jawa Barat. Institut Pertanian Bogor.

Soemarno. (2010). Model optimasi pengelolaan lahan. Retrieved from http://hbgloballtd.com/Agriculture.html

Subagyo, H., Suharta, N., \& Siswanto, A. B. (2000). Tanahtanah pertanian di Indonesia. In Sumberdaya lahan Indonesia dan pengelolaannya (1st ed.). Bogor: Pusat Penelitian Tanah dan Agroklimat Badan Penelitian dan Pengembangan Pertanian Departemen Pertanian.

Sys, C., Van Ranst, E., \& Debaveye, J. (1991). Land evaluation, part I: principles in land evaluation and crop production calculations. Agricultural Publications-NO 7, General Administration for Development Cooperation, Brussels, Belgium, p. 280. Brussels, Belgium: Agricultural Publications - No7.

Wirosuprojo, S. (2005). Klasifikasi lahan untuk perencanaan penggunaan lahan di kabupaten sleman daerah istimewa yogyakarta. Forum Perencanaan Pembangunan, 3, 24-30. 